\title{
THE DISTRIBUTION OF RED CELLS AND PLASMA IN LARGE AND MINUTE VESSELS OF THE NORMAL DOG, DETERMINED BY RADIOACTIVE ISOTOPES OF IRON AND IODINE ${ }^{1}$
}

\author{
By JOHN G. GIBSON, 2ND, ARNOLD M. SELIGMAN, WENDELL C. PEACOCK, \\ JOSEPH C. AUB, JACOB FINE, AND ROBLEY D. EVANS \\ (From the Departments of Medicine and Surgery, Harvard Medical School, the Medical Clinics \\ of the Peter Bent Brigham and the Massachusetts General Hospitals, and the \\ Surgical Research Department of the Beth Israel Hospital, Boston; \\ and the Radioactivity Center, Massachusetts Institute \\ of Technology, Cambridge)
}

(Received for publication August 20, 1946)

Sufficient evidence, both indirect and direct, has now appeared in the literature, to leave no reasonable doubt that the hematocrit of all the circulating blood in the body is normally always lower than that of blood samples drawn from large arteries or veins, or from the right auricle.

The indirect evidence has been discussed in a previous communication (1). Direct evidence lies in the fact that the circulating red cell volume determined by radioactive iron is consistently less than when measured at the same time in the same subject by the dye-plasma-hematocrit method in dogs (2) and in humans (1). Equivocal evidence is the finding of either larger or smaller red cell volume by the carbon monoxide than by the dye technique (3).

The relationship of the average body to venous hematocrit has been shown to vary within fairly small limits ( \pm 5 per cent) (1), and the ratio of average body to venous hematocrit is a constant, within the limits between venous hematocrit levels of from 11 to 50 (4) in dogs, and from 38 to 48 in man (1). These facts imply a fairly constant distribution of blood within large and minute vessels in the normal state. It therefore seemed advisable to make quantitative measurements of the quantity of plasma and red cells flowing through the large and small vessels in relation to the total measurable blood volume. The development of techniques of tagging red cells with radioactive iron (5) and plasma with iodine (6) made a di-

\footnotetext{
1 The work described in this paper was done under a contract, recommended by the Committee on Medical Research, between the Office of Scientific Research and Development and the Massachusetts Institute of Technology, in collaboration with the Peter Bent Brigham Hospital, the Massachusetts General Hospital and the Beth Israel Hospital, Boston.
}

rect attack on the problem possible. The studies on normal dogs reported herewith were undertaken as a control for subsequent work on the intravascular distribution of blood in experimental shock.

\section{METHODS}

All dogs were fasting (24 hours) and were maintained under light morphine narcosis (2 $\mathrm{mgm}$. per $\mathrm{kgm}$.) throughout the observation period. An initial plasma volume determination was made by the method of Gibson and Evelyn (7). At the same time, the dog received an infusion of freshly drawn compatible dog red cells tagged with $\mathrm{Fe}^{\mathrm{ss}}$, for the determination of circulating red cell volume. The dog was then allowed to walk about the laboratory at will. Three to 5 hours later, plasma volume was again determined, and an infusion of freshly drawn compatible dog red cells tagged with $\mathrm{Fe}^{\mathrm{s}}$ was given. At the same time an infusion of bovine albumin or fresh dog plasma iodinated with radioactive iodine $\left(\mathrm{I}^{121}\right)$ was given intravenously. The stability of the iodine linkage in such iodinated plasma protein, as well as the method of preparing and measuring its radioactivity in blood and tissues, is given in a previous publication by Fine and Seligman (6). Samples of blood were taken throughout a 1-hour period for measurement of plasma dye level and iodine radioactivity, measurement of the hematocrit and hemoglobin concentration of whole blood in the large vessels, and of the radioactivity level of both isotopes of iron in the red cells. The dog was then sacrificed by the intravenous injection of nembutal:

The animals were autopsied immediately after death, and the weight of the organs was recorded. Organs analyzed were spleen, liver, lung, kidneys, heart, bowel, muscle and brain. No bone marrow was obtained. The organs were not perfused, and no attempt was made to prevent blood from oozing out as the organs were cut up. Small pieces of tissue which avoided large vessels were gently wiped with gauze and weighed.

Representative samples of each organ were taken and finely divided. An aliquot of each organ was analyzed for hemoglobin (6), radioactive iodine (6), and both isotopes of radioactive iron. 
The content of plasma and red cells in the small vessels of each organ was calculated, in ml. per gram of tissue (6). The unit quantity of plasma was taken as the same proportionate radio-iodine activity of the tissue sample as the radio-iodine value of plasma samples at time of death was to the extrapolated plasma activity at the time of injection. The assumption was made that iodo-protein loss from the circulation between the time of injection and death occurred in all tissues to the same extent. The unit quantity of total red cells was based upon the relative concentration of hemoglobin in whole blood and that obtained by extraction of hemoglobin from tissue samples, as described by Fine and Seligman (6). The unit quantity of cells tagged with $\mathrm{Fe}^{56}$ and $\mathrm{Fe}^{50}$ respectively was based upon the relative radio-iron activities of both isotopes of a red cell sample drawn just prior to death, and the tissue sample. In making radio-iodine measurements in tissue, corrections were made for radioactivity due to radio-iron from red cells, but these were not significantly great in most instances. In 4 experiments, total red cell content was calculated from extracted hemoglobin values, and in 3 experiments from $\mathrm{Fe}^{\mathrm{ss}}$ values. Rapidly circulating red cell content was based upon $\mathrm{Fe}^{50}$ measurements in all instances. Total plasma and red cell content was taken as the product of unit content and organ weight. Iodine measurements reflect only circulating plasma.

The net amount of whole blood removed in sampling was less than 5 per cent of the initial total blood volume, and no significant changes in mean arterial pressure were observed. No correction of tissue values for bleeding were made.

The protocol of a typical experiment is given below, and illustrated in Figure 1. Therein is shown the ex- pected change from initial values in plasma, cell and whole blood volume due to the administration of whole blood and radio-iodo plasma for cell and plasma volume determinations. The determined final volumes were within 4 per cent of the expected values.

Table I summarizes the findings in Experiment No. 25-131. The unit values ( $\mathrm{ml}$. per gram of tissue) for plasma (by radio-iodo-protein), for total red cells (by $\mathrm{Fe}^{\mathrm{s}}$ ) and for circulating red cells (by $\mathrm{Fe}^{50}$ ), as well as for whole blood (the sum of plasma and circulating cells), are given for each of the 8 organs analyzed. The minute vessel content of plasma, red cells and whole blood is the product of the respective unit value and the weight of the organ. Also shown is the ratio of circulating to total red cells in the minute vessels for each organ, and also the hematocrit of whole blood for each organ. The minute vessel hematocrit was calculated from the circulating red cell content and the whole blood content.

The percentage of minute vessel content to total volume was 16.7 for plasma, 13.3 for circulating red cells, and 16.3 for whole blood respectively. The quantity of circulating red cells in minute vessels of all the organs was approximately equal to the quantity of total red cells. The weighted ratio of circulating to total red cells was 1.05; the arithmetic average of the ratios of the several organs was 1.02 .

The arterial hematocrit at the time of final volume measurement was 42.1 , the hematocrit of all the blood in circulation was 40 , while that of the blood in all the minute vessels was 32.6 .

A comparison of the values obtained in 4 experiments for the final plasma volume both by dye and by radioiodo-protein is given in Table II.

Protocol. Normal dog $11.8 \mathrm{kgm}$.

$11 / 8 / 43$ Exp. No. 25-131

\begin{tabular}{|c|c|c|c|c|c|c|c|c|c|c|c|c|}
\hline \multirow{2}{*}{ Time } & & \multirow{2}{*}{ Het. } & \multicolumn{3}{|c|}{ Given } & \multicolumn{3}{|c|}{ Bled } & \multirow{2}{*}{ M.A.P. } & \multirow{2}{*}{ Vrr } & \multirow{2}{*}{ Vpd } & \multirow{2}{*}{ Vrwp } \\
\hline & & & $\begin{array}{l}\text { Red } \\
\text { cells }\end{array}$ & Plasma & $\begin{array}{l}\text { Whole } \\
\text { blood }\end{array}$ & $\begin{array}{l}\text { Red } \\
\text { cells }\end{array}$ & Plasma & $\begin{array}{l}\text { Whole } \\
\text { blood }\end{array}$ & & & & \\
\hline 8:35 A. M. & $\begin{array}{l}\text { Morphine sulphate } 23.6 \mathrm{mg} \text {. } \\
\text { i.m. }\end{array}$ & per cent & $m l$. & $m l$. & $m l$. & $m l$. & $\mathrm{ml}$. & $m l$. & $\begin{array}{c}\text { mg. } H g . \\
95\end{array}$ & $m l$. & $m l$. & $m l$. \\
\hline $\begin{array}{l}10: 30 \\
10: 46 \\
11: 25\end{array}$ & $\begin{array}{l}\text { Blood tagged with } \mathrm{Fe}^{65} \text { i.v. } \\
3 \text { cc. } 0.1 \% \text { Evans Blue i.v. } \\
\text { Samples for volume I }\end{array}$ & $\begin{array}{l}45.8 \\
41.6\end{array}$ & 32 & 38 & 70 & 27 & 38 & 65 & 100 & 440 & 675 & 1115 \\
\hline $\begin{array}{l}11: 28 \\
2: 00 \text { P.M. } \\
2: 10 \\
2: 12 \\
2: 15 \\
2: 28 \\
3: 08\end{array}$ & $\begin{array}{l}\text { complete } \\
\text { Dog off table } \\
\text { Dog on table } \\
\text { Pre-volume II samples } \\
\text { Blood tagged with Fe } \text { e }^{50} \text { i.v. } \\
\text { Radio-iodo-albumin i.v. } \\
3 \text { cc. } 0.1 \% \text { Evans Blue i.v. }\end{array}$ & 41.3 & 29 & $\begin{array}{l}36 \\
14\end{array}$ & 65 & 6 & 9 & 15 & 110 & 460 & 600 & 1150 \\
\hline $\begin{array}{l}3: 09 \\
3: 11\end{array}$ & $\begin{array}{l}\text { Net change due to transfu- } \\
\text { sion and bleeding * } \\
\text { Expected volumes } \\
20 \text { cc. nembutal i.v. } \\
\text { Animal expired }\end{array}$ & 42.1 & & +13 & +9 & $\begin{array}{l}20 \\
-4\end{array}$ & 22 & $4 J$ & 110 & 436 & 692 & 1100 \\
\hline
\end{tabular}

* Computation does not include first transfusion or blood removed for samples after injection of radio-iodo-albumin. 
In Table III are shown the unit values for total red cells of the organs studied as measured by hemoglobin in 5 experiments and by $\mathrm{Fe}^{\mathrm{ss}}$ in 2 experiments. The spread of values for individual organs obtained by hemoglobin measurement was greater than that obtained by radioactivity analysis. The average unit values for the individual organs based on radioactivity measurements were larger than that based on hemoglobin measurements in 4 organs, and smaller in 4 organs. The averages of the unit values for each organ, however, are in essential agreement. The largest errors in hemoglobin technique were with myoglobin-containing tissues (skeletal muscle).

Table IV summarizes the findings obtained by the experimental procedure described in 7 normal dogs. Some of the data included were presented in a previous communication (8).

The range and average of intravascular content of red cells in minute vessels includes all values found by both hemoglobin and radio-iron for both total and circulating red cells, since, in the entire series of experiment, the ratio of circulating to total cells was found to be unity. Therefore the average unit values for the individual organs are somewhat different than the average values shown in Table III, in which only values for total cell values were compared.

The range of unit values for whole blood also represent extremes of red cell unit values and hence are not the arithmetic sums of average red cell and plasma unit values.

The per cent of total red cell plasma and whole blood in minute vessels was calculated from the circulating plasma and red cell volume and the final gross plasma and red cell volumes.

The values given for the hematocrit of blood in the minute vessels of each organ are arithmetic averages for the whole series of dogs. The arterial body and minute vessel hematocrits also are arithmetic.

The ratio of rapidly circulating to total red cells was $1.01 \pm 0.05$.

An average of 16.5 per cent of total red cells 20.4 of total plasma and 17.2 per cent of whole blood was found in the total minute vessels of the organs analyzed.

Table V shows the hematocrit of whole blood in arteries, in large vessels, in the entire body, and in minute

EXPERIMENT N0.25-131 NORMAL DOG 11.8 Ko. NOVEMBEn 8,1943

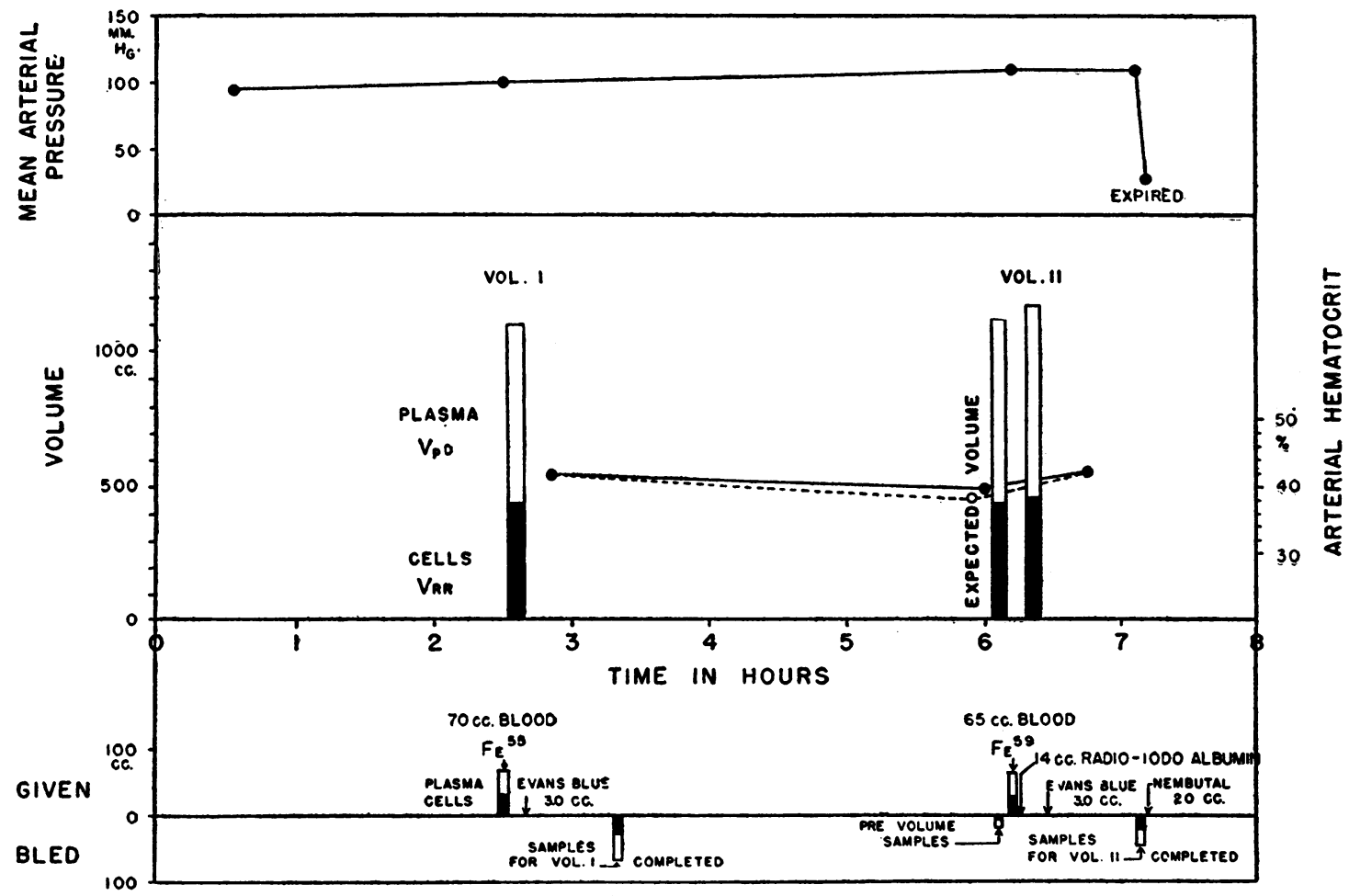

Fig. 1. Time Chart

This shows injection of erythrocytes tagged with $\mathrm{Fe}^{56}$ and $\mathrm{Fe}^{59}$ for determination of red cell volume, Evans Blue for determination of plasma volume, and radio-iodo-albumin for measurement of minute vessel plasma content. The final cell and plasma volume agreed well with the expected final volumes. 
TABLE I

The unit quantity and total content of plasma and red cells in the minute vessels of a normal dog Experiment No. 25-131. Normal Dog $11.8 \mathrm{Kg}$. Morphine narcosis.

November 8, 1943

\begin{tabular}{|c|c|c|c|c|c|c|c|c|c|c|}
\hline \multirow{3}{*}{ Organ } & \multirow{3}{*}{ Weight } & \multirow{3}{*}{ Plasma } & \multirow{2}{*}{\multicolumn{2}{|c|}{ Red cells }} & \multicolumn{4}{|c|}{ Organ minute vessel content } & \multirow{3}{*}{ f2† } & \multirow{3}{*}{$\begin{array}{l}\text { Minut } \\
\text { vessel } \\
\text { Hct.* }\end{array}$} \\
\hline & & & & & \multirow{2}{*}{ Plasma } & \multicolumn{2}{|c|}{ Red cells } & \multirow{2}{*}{$\begin{array}{l}\text { Whole } \\
\text { blood* }\end{array}$} & & \\
\hline & & & $\mathrm{Few}^{\mathrm{w}}$ & $\mathrm{Fe}^{50}$ & & Total & Circulating & & & \\
\hline $\begin{array}{l}\text { Spleen } \\
\text { Lungs } \\
\text { Liver } \\
\text { Kidneys } \\
\text { Heart } \\
\text { G. I. tract } \\
\text { Musclef } \\
\text { Brain }\end{array}$ & $\begin{array}{r}\text { grams } \\
72 \\
99 \\
252 \\
58 \\
83 \\
350 \\
3540 \\
62\end{array}$ & $\begin{array}{l}\text { ml. per } \\
\text { gram } \\
.068 \\
.201 \\
.128 \\
.074 \\
.051 \\
.035 \\
.0103 \\
.0109\end{array}$ & $\begin{array}{l}\text { ml. per } \\
\text { gram } \\
.393 \\
.107 \\
.020 \\
.006 \\
.015 \\
.006 \\
.003 \\
.003\end{array}$ & $\begin{array}{l}\text { ml. per } \\
\text { gram } \\
.442 \\
.100 \\
.019 \\
.007 \\
.015 \\
.006 \\
.003 \\
.003\end{array}$ & \begin{aligned} \multicolumn{1}{c}{$m l} \\
4.9 \\
20.0 \\
32.3 \\
4.3 \\
4.3 \\
12.3 \\
36.5 \\
1.8\end{aligned}$. & \begin{aligned} \multicolumn{1}{c}{$m l} \\
28.20 \\
10.60 \\
5.05 \\
0.35 \\
1.25 \\
2.10 \\
10.60 \\
0.18\end{aligned}$. & \begin{tabular}{r}
\multicolumn{1}{c}{$m l}$. \\
31.80 \\
9.90 \\
4.80 \\
0.40 \\
1.25 \\
2.10 \\
10.60 \\
0.18
\end{tabular} & \begin{aligned} \multicolumn{1}{c}{$m l} \\
36.70 \\
29.90 \\
37.10 \\
4.70 \\
5.55 \\
14.40 \\
57.10 \\
1.98\end{aligned}$. & $\begin{array}{l}1.12 \\
0.93 \\
0.95 \\
1.16 \\
1.00 \\
1.00 \\
1.00 \\
1.00\end{array}$ & $\begin{array}{r}87 \\
33 \\
13 \\
9 \\
22 \\
15 \\
19 \\
9\end{array}$ \\
\hline \multicolumn{5}{|c|}{$\begin{array}{l}\text { Totals } \\
\text { Averages } \\
\text { Final volumes } \\
\text { Percentage of total } \\
\text { Percentage of total } \\
\text { Body hematocrit ( } f \\
\text { Arterial hematocrit }\end{array}$} & $\begin{array}{r}115.4 \\
690.0 \\
16.7 \\
83.3\end{array}$ & 58.33 & $\begin{array}{c}61.03 \\
460.0 \\
13.3 \\
86.7\end{array}$ & $\begin{array}{r}187.43 \\
1150.0 \\
16.3 \\
83.7\end{array}$ & 1.028 & $\begin{array}{l}40.0 \\
42.1\end{array}$ \\
\hline
\end{tabular}

* Based on plasma and circulating cell content.

t Ratio of circulating to total red cells.

$\$$ Estimated as $\frac{1}{2}$ of body weight.

\& Arithmetic average of individual f2 values. Weighted average is 1.05 .

II Based on total circulating red cells and plasma in minute vessels.

vessels. The averages of the ratios of these hematocrits to the arterial hematocrits were $0.92,0.85$ and 0.68 respectively.

\section{DISCUSSION}

Several aspects of the techniques used warrant consideration.

Plasma volumes were calculated from radioiodo-protein data in 4 experiments. The values were within \pm 10 per cent of the values obtained by the dye method (Table II), and this agreement constitutes a check on the reliability of the unit

TABLE II

Plasma volume measured by both the dye method and by radio-iodo-albumin

\begin{tabular}{c|c|c|c|c}
\hline \hline & \multicolumn{2}{|c|}{ Plasma volume } & & Difference \\
\cline { 2 - 3 } & Bxp. no. & Error* \\
& By dye & $\begin{array}{c}\text { By radio- } \\
\text { iodo-albumin }\end{array}$ & & \\
\hline & $m l$. & $m l$. & $m l$. & per cent \\
111 & 1390 & 1335 & -55 & -4 \\
113 & 990 & 1180 & +90 & +9 \\
114 & 800 & 840 & +20 & +5 \\
127 & 690 & 670 & -20 & -3 \\
\hline
\end{tabular}

* Percentage by which plasma volume by radio-iodoprotein differed from value by dye method. values of plasma in the minute vessels of the organs analyzed. The tagged red cells transfused were compatible with the serum of the recipient dog. These red cells were freshly drawn in heparin, and there was no evidence of any breakdown of those cells in the subject animal. Consequently, all the measured radioactivity of iron of the samples derived only from intact erythrocytes, and none from tissue iron.

The radioactivity measurements obtained were sufficiently higher than instrumental background to be significant in all samples of both red cells and organs. The probable error of the lowest measurements was no greater than that of the highest measurements.

The manner in which the organs were cut up was such that only blood in very small vessels was included in the samples analyzed. Brain, heart, kidneys and spleen were completely divided into pieces measuring not over a few $\mathrm{mm}$. in the longest dimension. Portions of each lobe of the liver, of each lobe of the lungs, of the cardiac and pyloric portions of the stomach, sections of duodenum, jejunum and colon, and sections of neck, 
TABLE III

Total red cell content of minute vessels as measured by hemoglobin and by radioactive iron analyses of tissue samples *

\begin{tabular}{|c|c|c|c|c|c|c|c|c|c|}
\hline \multirow[t]{2}{*}{ Exp. no. } & 100 & 109 & 111 & 113 & 114 & 127 & 131 & \multicolumn{2}{|c|}{ Averages } \\
\hline & \multicolumn{5}{|c|}{ By hemoglobin } & \multicolumn{2}{|c|}{ By radio-iron } & By hb & $\begin{array}{c}\text { By } \\
\text { radio- } \\
\text { iron }\end{array}$ \\
\hline $\begin{array}{l}\text { Spleen } \\
\text { Liver } \\
\text { Lungs } \\
\text { Kidney } \\
\text { Heart } \\
\text { G. I. tract } \\
\text { Muscle } \\
\text { Brain }\end{array}$ & $\begin{array}{l}.100 \\
.160 \\
.010 \\
.015 \\
.027 \\
.006 \\
.002\end{array}$ & $\begin{array}{l}.370 \\
.030 \\
.053 \\
.050 \\
.006 \\
.040 \\
.006\end{array}$ & $\begin{array}{l}.283 \\
.038 \\
.057 \\
.046 \\
.013 \\
.004 \\
.005\end{array}$ & $\begin{array}{l}.340 \\
.035 \\
.074 \\
.046 \\
.006 \\
.013 \\
.007\end{array}$ & $\begin{array}{l}.018 \\
.050 \\
.048 \\
.012 \\
.005 \\
.004\end{array}$ & $\begin{array}{l}.338 \\
.057 \\
.081 \\
.032 \\
.013 \\
.027 \\
.004 \\
.003\end{array}$ & $\begin{array}{l}.363 \\
.020 \\
.107 \\
.040 \\
.015 \\
.006 \\
.004 \\
.003\end{array}$ & $\begin{array}{l}.331 \\
.038 \\
.080 \\
.040 \\
.011 \\
.020 \\
.006 \\
.002\end{array}$ & $\begin{array}{l}.350 \\
.038 \\
.094 \\
.036 \\
.014 \\
.016 \\
.004 \\
.003\end{array}$ \\
\hline
\end{tabular}

* All values are for ml. of red cells per gram of tissue.

back, abdominal and both leg muscles were cut up in the same way. The organs were not perfused, nor was their blood supply tied off prior to removal from the body. All of the blood that would was allowed to drain out during sectioning, but the cut pieces were not squeezed; the surfaces were gently wiped. Visible vessels were excluded from samples. The pieces of organ in the aliquot processed were selected to be representative of all parts of the organ. Thus it was felt that the blood examined came from vessels not larger than arterioles or venules. Bone, bone marrow, fat, and the mesentery were not examined. Since the skin of the dog was found to be virtually bloodless, it was not routinely assayed.

The total muscle weight was estimated as $1 / 3$ of the total body weight, since that was the proportion found in many dogs in another study (9) in which practically all of the skeletal muscle was removed from the bones. It was felt this estimate was sufficiently accurate for our purpose, so that this laborious and time-consuming process could be dispensed with.

It was assumed that hemoglobin extracted from tissue samples was an accurate measure of the total red cells in the blood vessels, except in the case of muscle samples which contain myoglobin and therefore required separate extraction of myoglobin with saline before extraction of hemoglobin with water (6).

In 5 experiments, the total red cell unit value was based on the hemoglobin content; and in 2, on $\mathrm{Fe}^{55}$ radioactivities. The red cells were leached out of very finely divided, but not crushed, pieces of tissue with water in the cold for 24 hours.
Hemoglobin was measured with the Klett photoelectric colorimeter, after clearing with ammonium hydroxide, at 540, 560 and $620 \mu \mu$. Turbidity was especially troublesome in samples from gut, kidney, liver and lungs.

The spread of values obtained by hemoglobin extraction was much greater than that obtained with $\mathrm{Fe}^{55}$ measurements. This is undoubtedly due to the inaccuracy of the former method. There is a very close agreement between the unit values obtained by both techniques, so that the measurement of total cells by $\mathrm{Fe}^{55}$ radioactivity values in 2 experiments appears to have been warranted.

Scrutiny of data in Table IV reveals several points of interest. At once striking is the very small quantity of both cells and plasma per gram of tissue in all organs. The largest unit value of whole blood was found in the spleen, about 400 cu. mm. per gram. Liver, lungs, and kidneys contained about $1 / 2$ as much, and heart and gastrointestinal tract about $1 / 7$ as much as the spleen. Skeletal muscle and the brain contained very small quantities of whole blood.

A total of 17 per cent of the entire whole blood volume was found in the minute vessels of all the organs. This is about the figure given by authors who have computed the volume of the capillary bed under normal conditions (10). A somewhat greater proportion of the total plasma volume and a somewhat smaller proportion of the total red cells was in the minute vessels.

The greatest amount of whole blood was found in the liver, and in the skeletal muscle, from 5 to 6 per cent. From 1 to 2 per cent was found in 


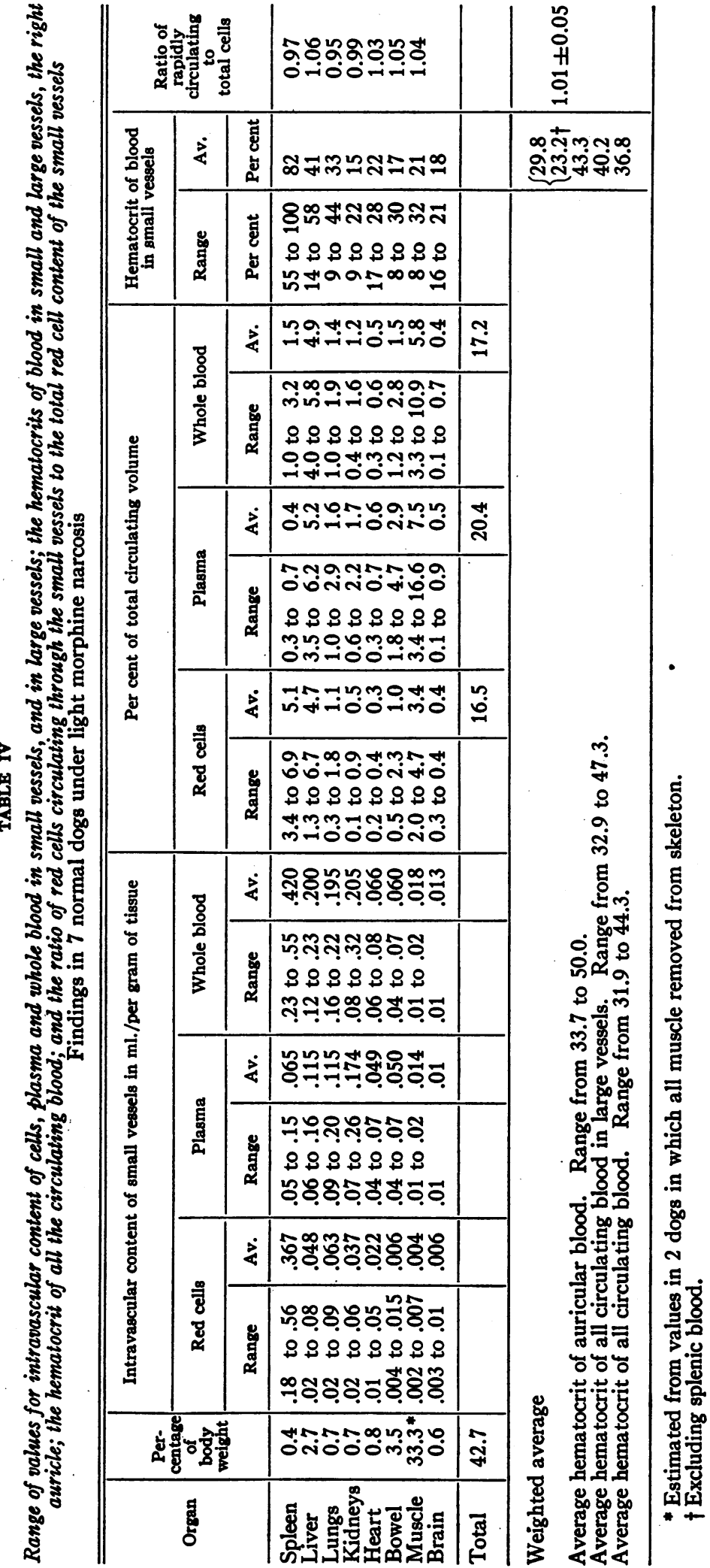


TABLE V

The hematocrits of whole blood in large and minute vessels and of the whole body compared to the arterial hematocrit

\begin{tabular}{l|c|c|c|c|c|c|c}
\hline \hline \multicolumn{1}{|c|}{ Experiment no. } & 111 & 113 & $114^{*}$ & 127 & 131 & Av. & $\begin{array}{c}\text { Ratio } \\
\text { to ar- } \\
\text { terial } \\
\text { hct. }\end{array}$ \\
\hline $\begin{array}{l}\text { Arterial or } \\
\text { venous }\end{array}$ & 44.6 & 46.7 & 50.0 & 33.7 & 42.3 & 43.3 & 1.0 \\
$\begin{array}{l}\text { Large vessels } \\
\text { Body } \\
\text { Minute vessels }\end{array}$ & 33.9 & 46.0 & 47.3 & 32.9 & 40.6 & 40.2 & 0.92 \\
\hline
\end{tabular}

* Splenectomized dog.

spleen, lungs, kidneys and gut, while brain and heart contained less than 1 per cent.

While a very small portion of total whole blood volume was found in the spleen, this amount is a sizeable proportion, from $1 / 10$ to $1 / 5$ of the total whole blood in the minute vessels.

The hematocrit of whole blood in each organ varied greatly in individual dogs, by as much as a factor of 4 . The average values given in Table IV are weighted. There were marked differences in these values for the several organs. The he- matocrit of splenic blood was higher than that of any other organ, and also higher than that of arterial or venous blood. Liver blood had an hematocrit about equal to arterial blood, while pulmonary blood had a definitely lower hematocrit. The hematocrits of blood in all the other organs is about $1 / 2$ that of arterial blood.

Thus it is apparent that the cell to plasma ratio of a great part of blood in capillaries is very low. It is quite possible that this low ratio is in some way related to the speed of flow through various organs, and to the larger intimal surface area of capillaries as compared to artery. Circulation in the spleen, which had the highest hematocrit value, is known to be sluggish, while flow through kidney and heart, which had the lowest hematocrit values, is far more rapid. Liver and spleen have sinusoidal vessels which are of larger calibre than capillaries, and therefore have proportionately less surface that must be wetted by plasma.

The hematocrit of all the blood in the body was lower than the arterial hematocrit in all 5 dogs, by an average value of 85 per cent. The minute

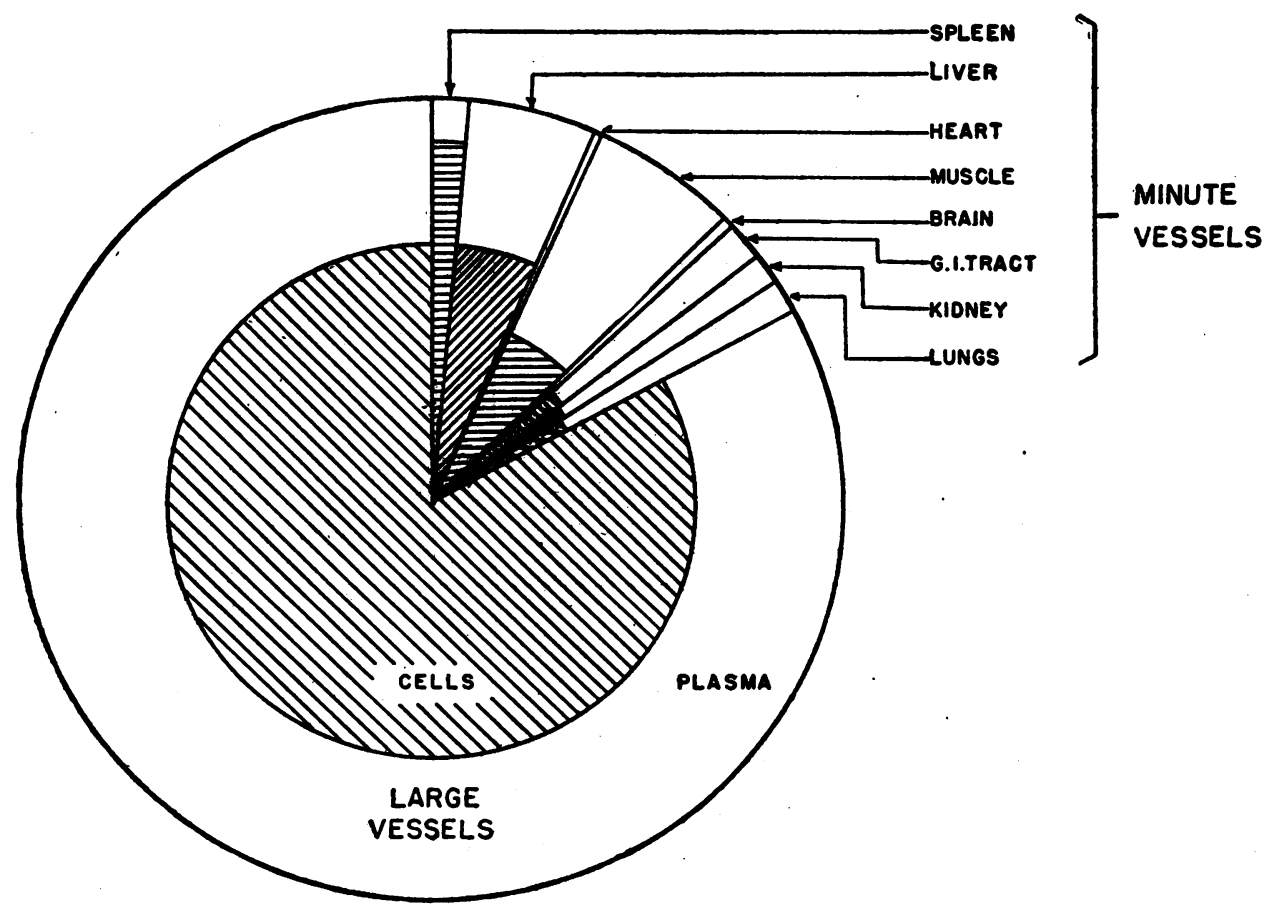

Fig. 2. The Rerative Distribution of Whole Blood, Cells and Plasma in the Large and Minute Vessels

The hematocrits of whole blood in the large vessels, and in the several organs are indicated by the segments of the inner circles. 
vessel hematocrit was considerably lower and the large vessel hematocrit slightly higher than the body hematocrit. Figure 2 shows the relative distribution of whole blood and the relative concentration of red cells, in both the large and minute vessels.

In a previous communication (1) we reported the ratio of red cell volume measured simultaneously by radio-iron and dye averaged 0.85 in 40 normal males, and 0.83 in 40 normal dogs. As shown in Table $\mathrm{V}$, this ratio, in 4 dogs in which all organs including the spleen were studied, averaged 0.85 . It was of interest to ascertain what corresponding ratio would be obtained when the calculation thereof was based on the quantities of red cells and plasma in minute vessels, determined directly by radio-iron and radio-iodine measurements. This analysis is given in Table VI. To determine red cell volume, the percentage of whole blood in the minute vessels is multiplied by the ratio of the hematocrit of that blood. Large, vessel blood is considered as the difference between total blood volume measured by dye and radioiron, and the minute vessel blood. The percentage of whole blood in the large vessels is also multiplied by the ratio of the hematocrit of that blood, and the 2 products are added. For example,

Whole blood in large vessels $=82.8$ per cent of total blood.

Whole blood in minute vessels $=17.2$ per cent of total blood.

The ratio of hematocrit of large vessel blood and of minute vessel blood to arterial hematocrit are 0.92 and 0.68 respectively.

Then,

$$
\begin{aligned}
.828 \times 0.92 & =.763 \\
.172 \times 0.68= & \frac{.117}{.880} \\
& =\mathrm{Vrr} / \mathrm{Vrpd} \text { or } \mathrm{Vrpd} / \mathrm{Vrr}=1.14
\end{aligned}
$$

There was fairly good agreement between this value and the value for $\mathrm{Vrr} / \mathrm{Vrpd}$ based on gross volume determinations in all experiments. The ratio based on minute vessel measurements averaged 0.88 , that based on gross volume measurements averaged 0.85 . This agreement constitutes an excellent internal check on the accuracy of all tissue measurements.

These observations fully explain why Vrr is consistently 85 per cent of Vrpd in the normal state.

TABLE VI

\begin{tabular}{|c|c|c|c|c|c|}
\hline & \multicolumn{4}{|c|}{ Experiment no.* } & \multirow{2}{*}{ Averages } \\
\hline & 111 & 113 & 127 & 131 & \\
\hline \multicolumn{6}{|c|}{ Calculations based on direct radio-iron and radio-iodine analyses } \\
\hline $\begin{array}{l}\text { Fraction of whole blood in minute vessels } \\
\text { Ratio of minute vessels to arterial Hct. } \\
\text { Whole blood } x \text { ratio of hematocrits }\end{array}$ & $\begin{array}{l}0.172 \\
0.54 \\
0.093\end{array}$ & $\begin{array}{l}0.171 \\
0.77 \\
0.133\end{array}$ & $\begin{array}{l}0.152 \\
0.78 \\
0.12\end{array}$ & $\begin{array}{l}0.162 \\
0.61 \\
0.10\end{array}$ & $\begin{array}{l}0.164 \\
0.675 \\
0.112\end{array}$ \\
\hline $\begin{array}{l}\text { Fraction of whole blood in large vessels } \\
\text { Ratio of large vessel to arterial Hct. } \\
\text { Whole blood } x \text { ratio of hematocrits }\end{array}$ & $\begin{array}{l}0.828 \\
0.76 \\
0.63\end{array}$ & $\begin{array}{l}0.829 \\
0.98 \\
0.81\end{array}$ & $\begin{array}{l}0.848 \\
0.99 \\
0.85\end{array}$ & $\begin{array}{l}0.838 \\
0.93 \\
0.78\end{array}$ & $\begin{array}{l}0.836 \\
0.915 \\
0.768\end{array}$ \\
\hline $\begin{array}{l}\text { Sum of whole blood in minute and large } \\
\text { vessels x ratio of hematocrits }\end{array}$ & 0.72 & 0.94 & 0.97 & 0.88 & 0.880 \\
\hline \multicolumn{6}{|c|}{ Calculations based on gross red cell (by radio-iron) and plasma volumes (by dye method) } \\
\hline $\begin{array}{l}\text { Red cell volume by radio-iron } \\
\text { Plasma volume by dye method } \\
\text { Whole blood volume by dye method } \\
\text { Red cell volume by dye method } \\
\text { Ratio of Vrr to Vrpd }\end{array}$ & $\begin{array}{l}m l . \\
650 \\
1390 \\
2510 \\
1120 \\
0.58\end{array}$ & $\begin{array}{c}m l . \\
780 \\
945 \\
1770 \\
825 \\
0.95\end{array}$ & $\begin{array}{c}m l . \\
345 \\
740 \\
1100 \\
360 \\
0.96\end{array}$ & $\begin{array}{c}m l . \\
463 \\
690 \\
1220 \\
530 \\
0.88\end{array}$ & 0.842 \\
\hline
\end{tabular}

Relationship of whole body to arterial hematocrit based on direct radioactivity measurements of cells and plasma in minute vessels, compared to the same ratio obtained by gross radio-iron red cell volume measurements

* Experiment No. 114, splenectomized dog, is excluded. 
Since Vrpd is always calculated from the plasma volume and auricular arterial or venous hematocrit, it follows that true red cell volume is also over-estimated by about 15 per cent by the dye method. The agreement of the above value, 0.88 , with the values obtained by gross volume measurements of 0.85 for normal humans and 0.83 for normal dogs, is convincing evidence, in 2 independent sets of experiments, in support of the above statement.

The ratio of rapidly circulating to total red cells is a measure of the completeness with which the second infusion of tagged red cells has become mixed with all the red cells within the entire vascular bed. If this ratio is 1.0 , it indicates complete mixing. If it is less than 1.0, it indicates that some fraction of the total red cells are no longer in active circulation. A ratio greater than 1.0 is theoretically impossible.

The ratios for the several organs varied from 0.95 to 1.06 , averaging $1.01 \pm 0.05$. Thus all values are well within the limit of error of the techniques employed. We conclude that in the normal dog all of the red cells within the vascular bed are in active circulation. It follows that no reserves of erythrocytes exist in the body of the dog in the organs studied.

These studies do not disclose what quantities of mature cells may be in bone marrow. Since the normal rate of erythrocyte production is only 1 per cent of total red cell volume per day, it is extremely doubtful if bone marrow can be considered as a reserve of any significance. These facts invalidate the hypotheses of Wollheim (11), Levin (12) and Goldbloom and Lieberson (13), who considered the so-called "blood depots" of such a magnitude as to contain an amount of red cells almost equal to the quantity in active circulation.

The spleen has been thought of as a great blood depot. Contraction of that organ through sympathetic or adrenalin stimulation was thought of as flushing a great number of red cells into the vascular bed. This contention seemed to be supported by an increase in the hematocrit of venous blood following the administration of adrenalin, which was considered as evidence of an increase in total circulating red cell volume (14). Hahn (15) has shown that while this rise in hematocrit is produced by adrenalin in dogs, there is no corresponding change in the circulating red cell mass as directly measured by means of infused red cells tagged with radio-iron, and suggests that the rise in hematocrit may be due to redistribution of red cells brought about by vasoconstriction.

The total amount of red cells found in the spleen in these experiments was less than $\mathbf{5}$ per cent of the total red cell volume. These animals were sacrificed, and there is the possibility that a terminal contraction of the spleen, which would have emptied the sinusoids of some of their red cell content, may have occurred. However, the spleens were soft and did not appear to be contracted. Hahn has shown (16) that nembutal in anesthetic doses may cause the spleen to relax and become engorged with blood. It does not follow that a similar reaction is induced by sudden massive lethal doses of nembutal.

The experiments described were an attempt to study one aspect of the dynamics of the circulation. It should be emphasized that the volume techniques employed measure only plasma and red cells in active circulation. Therefore the values obtained are an expression of the amount of blood flowing through the organs at a given time.

The content of plasma and red cells found in these studies represents the status in the normal dog. This relationship may well change in abnormal circulatory conditions, as a result of extreme vasoconstriction or vasodilation. These studies present no data on the expansibility or contractability of the minute vessel plexus.

The most striking finding is the extremely small fraction of the total blood mass that is actually flowing through the nutrient vessels of the body at any one time. Only $1 / 5$ of the blood is performing metabolic work at any one time, the remaining $4 / 5$ being in transit to and from the site of cellular life processes and the sources of oxygen and food supply. The extent to which this may be thrown out of adjustment by experimental procedures which induce peripheral vascular collapse will be reported in subsequent communications.

\section{CONCLUSIONS}

1. Seventeen per cent of the total whole blood volume is within the minute vessels (arterioles, capillaries and venules) of the normal dog under light morphine narcosis.

2. The unit values of whole blood ( $\mathrm{ml}$. per gram of tissue) of the various tissues range in order of 
magnitude as follows: spleen $0.4 \mathrm{ml}$; liver, lungs and kidneys $0.2 \mathrm{ml}$; heart and gastrointestinal tract $0.06 \mathrm{ml}$.; and skeletal muscle and brain 0.02 $\mathrm{ml}$.

3. The percentage of total whole blood volume in the various organs is: skeletal muscle, 7 per cent; liver, 5 per cent; spleen, lungs, kidneys, gastrointestinal tract (excluding mesentery), from 1 to 2 per cent each; heart and brain, less than 1 per cent each.

4. The hematocrit of blood in the several organs, in animals with an average arterial hematocrit of 43 are approximately: spleen, 80 ; liver, 40 ; lungs, 35 ; heart'and skeletal muscle, 20 to 25 ; and kidney, gastrointestinal tract and brain, 15 to 20 .

5. The hematocrit of the blood in the large vessels, of all the blood in the body, and of the blood in the minute vessels, is always less than that of arterial or venous blood. The ratios of the partition hematocrits to the arterial hematocrit are approximately $0.9,0.85$ and 0.7 respectively.

6. The ratio of rapidly circulating to total red cells in the several organs is unity. Hence all red cells in the vascular bed are in active circulation, and no reserves of red cells exist in the normal dog.

\section{BIBLIOGRAPHY}

1. Gibson, J. G., 2nd, Peacock, W. C., Seligman, A. M., and Sack, T., Circulating red cell volume measured simultaneously by the radioactive iron and dye methods. J. Clin. Invest., 1946, 25, 838.

2. Hahn, P. F., Ross, J. F., Bale, W. F., and Balfour, W. M., Red cell and plasma volumes (circulating and total) as determined by radio iron and by dye. J. Exper. Med., 1942, 75, 221.

3. Hopper, J., Tabor, H., and Winkler, A. W., Simultaneous measurements of the blood volume in man and dog by means of Evans blue dye, T-1824, and by means of carbon monoxide. I. Normal subjects. J. Clin. Invest., 1944, 23, 628.
4. Hahn, P. F., and Bale, W. F., Linear relationship between the circulating red cell mass and the venous hematocrit as determined with radioactive iron. Am. J. Physiol., 1942, 136, 314.

5. Peacock, W. C., Evans, R. D., Irvine, J. W., Jr., Good, W. M., Kip, A. F., Weiss, S., and Gibson, J. G., 2nd, The use of two radioactive isotopes of iron in tracer studies of erythrocytes. J. Clin. Invest., 1946, 25, 605.

6. Fine, J., and Seligman, A. M., Traumatic shock: VII. A study of the problem of the "lost plasma" in hemorrhagic, tourniquet, and burn shock by the use of radioactive iodo-plasma protein. J. Clin. Invest., 1944, 23, 720.

7. Gibson, J. G., 2nd, and Evelyn, K. A., Clinical studies of the blood volume. IV. Adaptation of the method to the photoelectric microcolorimeter. J. Clin. Invest., 1938, 17, 153.

8. Fine, J., and Seligman, A. M., Traumatic shock. An experimental study including evidence against the capillary leakage hypothesis. Ann. Surg., 1943, 118, 238.

9. Fine, J., and Seligman, A. M., Unpublished data.

10. Schleier, J., Der Energieverbrauch in der Blutbahn. Pflüger's Arch. f. d. ges. Physiol., 1918, 173, 172.

11. Wollheim, E., Die Bestimmung der zirkulierenden Blutmenge. Ztschr. f. klin. Med., 1928, 108, 463.

12. Levin, $\mathrm{E} ., \mathrm{El}$ volumen de la sangre circulante y sus variaciones normales y patológicas: Estudio clinícoexperimental. Con prefacio del Bernardo A. Houssay. Rosario: Estab. Graf. Pomponio, 1938, pp. $36-44$, inc.

13. Goldbloom, A. A., and Lieberson, A., Clinical studies in circulatory adjustments. V. Clinical evaluation of cardiodynamic studies. Am. J. M. Sc., 1939, 197, 182.

14. Barcroft, J., Recent knowledge of the spleen. Lancet, 1925, 1, 319.

15. Hahn, P. F., Bale, W. F., and Bonner, J. F., Jr., Mechanism of the effect of epinephrine on the venous hematocrit value of the normal unanesthetized dog. Am. J. Physiol., 1942, 137, 717.

16. Hahn, P. F., Bale, W. F., and Bonner, J. F., Jr., Removal of red cells from the active circulation by sodium pentobarbital. Am. J. Physiol., 1943, 138, 415. 